\title{
The Duplicated Y-specific amhy Gene Is Conserved and Linked to Maleness in Silversides of the Genus Odontesthes
}

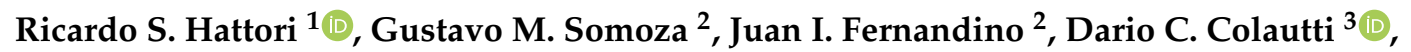 \\ Kaho Miyoshi ${ }^{4}$, Zhuang Gong ${ }^{5}$, Yoji Yamamoto ${ }^{4}$ and Carlos A. Strüssmann ${ }^{4, *}$ \\ 1 Unidade de Pesquisa e Desenvolvimento de Campos do Jordão, Sao Paulo Fisheries Institue, APTA/SAA, \\ Campos do Jordão 12460-000, Brazil \\ 2 Instituto Tecnológico de Chascomús (Consejo Nacional de Investigaciones Científicasy \\ Técnicas-Universidad Nacional de San Martin), Chascomús 7130, Argentina \\ 3 Instituto de Limnología “Dr. Raúl A. Ringuelet" (ILPLA) (Consejo Nacional de Investigaciones Científicasy \\ Técnicas-Universidad Nacional de La Plata), La Plata 1900, Argentina \\ 4 Graduate School of Marine Science and Technology, Tokyo University of Marine Science and Technology, \\ 4-5-7 Konan, Minato, Tokyo 108-8477, Japan \\ 5 School of Marine Science and Technology, Zhejiang Ocean University, Zhoushan 316002, China \\ * Correspondence: carlos@kaiyodai.ac.jp; Tel.: +81-3-5463-0541
}

Received: 15 August 2019; Accepted: 3 September 2019; Published: 5 September 2019

\begin{abstract}
Sex-determining genes have been successively isolated in several teleosts. In Odontesthes hatcheri and O. bonariensis, the amhy gene has been identified as a master sex-determining gene. However, whether this gene is conserved along related species is still unknown. In this study, the presence of amhy and its association with phenotypic sex was analyzed in 10 species of Odontesthes genus. The primer sets from $O$. hatcher $i$ that amplify both amhs successfully generated fragments that correspond to amha and amhy in all species. The full sequences of amhy and amha isolated for four key species revealed higher identity values among presumptive amhy, including the $0.5 \mathrm{Kbp}$ insertion in the third intron and amhy-specific insertions/deletions. Amha was present in all specimens, regardless of species and sex, whereas amhy was amplified in most but not all phenotypic males. Complete association between amhy-homologue with maleness was found in $O$. argentinensis, $O$. incisa, O. mauleanum, O. perugiae, O. piquava, O. regia, and O. smitti, whereas O. humensis, O. mirinensis, and O. nigricans showed varied degrees of phenotypic/genotypic sex mismatch. The conservation of amhy gene in Odontesthes provide an interesting framework to study the evolution and the ecological interactions of genotypic and environmental sex determination in this group.
\end{abstract}

Keywords: Temperature-dependent sex determination (TSD); Genotypic sex determination (GSD); pejerrey; sex determination

\section{Introduction}

The construction of detailed genetic maps while using microsatellites and single nucleotide length polymorphism (SNP) markers, complete genome sequencing, and transcriptome analysis pipelines have promoted the discovery of sex-determining genes in an increasing number of teleost fish. Such findings are uncovering a remarkable variety of master genetic switches of genotypic sex determination in this group of vertebrates [1,2], which is in line with the wide repertoire of reproductive strategies already reported in fish [3]. While there are at least three different sex-determining genes described in Oryzias genus [4-6], the $s d Y$ gene, initially characterized in rainbow trout [7], shows a high conservation across Salmonidae family members [8]. The discovery of new sex-determining genes has helped to 
shed light on the evolutionary mechanisms behind their appearance, which at present include allelic diversification and gene duplication, followed by chromosome transposition [2].

An interesting trend is the increasing number of reports of TGF-beta superfamily members' involvement in male sex determination. One example is the amh gene, a glycoprotein that is expressed by Sertoli cells that encodes for the homologue of the mammalian anti-Müllerian hormone. Although the roles of fish Amh have not been fully clarified, it has been associated with the control of germ cell proliferation [9]. In Odontesthes hatcheri (Atheriniformes, Atherinopsidae), amhy (Y chromosome-linked anti-Müllerian hormone), a male-specific amh gene that arises from a duplication of the autosomal amh gene amha was identified as a male determinant [10]. amhy has been found also in the congeneric $O$. bonariensis, the teleost with the strongest thermal sensitivity of sex determination (e.g., temperature-dependent sex determination, or TSD) reported so far [11]. Furthermore, amhy-like genes have also been described in the cobaltcap silverside Hypoatherina tsurugae, which is an atheriniform from the Atherinidae family [12], the Nile tilapia [13], and more recently in the Northern pike [14]. The receptor of amh gene amhrII was also described as the sex-determining gene in Takifugu rubripes and subsequently in other two congeners [15,16], highlighting the importance of Amh-AmhrII signaling in sex determination.

The availability of a sex-linked gene in atherinopsids is important, not only to study the evolution of sex determination mechanisms, but also as a molecular tool for assessing environmental impacts on gonadal sex differentiation in wild fish. For example, amhy could be used to detect phenotypic/genotypic sex mismatches such as (sex-reversed) XX males or XY females and study their association with unusual environment conditions and/or chemical pollutants with endocrine-disrupting properties. In addition, in O. bonariensis, the amhy gene can be used to detect $Y Y$ genotypes, which are expected from mating between sex-reversed XY females and XY males, and that are both viable and fertile in this species [17].

The atherinopsids from Odontesthes genus are distributed in the Central and Southern regions of South America and they are mainly estuarine and coastal-marine species but some species inhabit freshwater environments [18]. They comprise important fisheries resources and also present great ecological importance as forage species. Cytogenetic studies revealed a conserved diploid number of 48 chromosomes and the absence of morphologically distinguishable sex chromosomes in three in Odontesthes species $[10,19,20]$. This study investigated whether the amhy gene is conserved in 10 species of the Odontesthes genus from both the Pacific and Atlantic coasts, as well as some inland habitats, since information on genotypic sex determination of atherinopsids is limited to O. hatcheri and $O$. bonariensis. We also characterized the structure of those genes in four key species and examined the genetic association between amhy and maleness in wild-caught specimens.

\section{Materials and Methods}

\subsection{Sample Collection and Species Identification}

Materials for this study were collected using gillnets or seine in various localities that are shown in Figure 1 and Table 1. Specimens were identified through morphological and morphometric characters according to Dyer [18] and confirmed by sequence analysis of $c y t b$ gene in two specimens from each species. The amplification of $c y t b$ was performed using the primers listed in Table S1, following the procedures described in the next session. Sequences were compared with those that are available in GenBank database. All of the procedures were carried out in accordance with the guidelines for the care and use of animals issued by Sao Paulo Fisheries Institute under the CEEAIP 07/2018, issued on July 2018. 


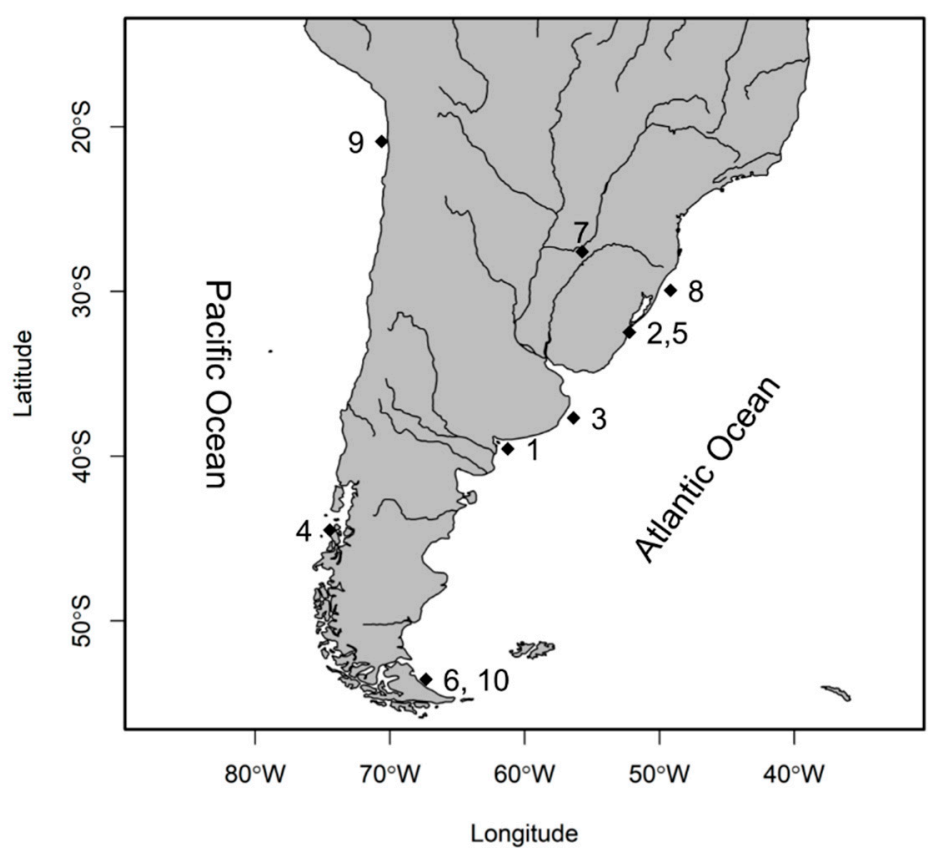

Figure 1. Location of collection sites of Odontesthes specimens in South America. 1: O. argentinensis, 2: O. humensis, 3: O. incisa, 4: O. mauleanum, 5: O. mirinensis, 6: O. nigricans, 7: O. perugiae, 8: O. piquava, 9: O. regia, and 10: O. smitti.

Table 1. Information on the location and type of environment of the collection sites, number and sex of specimens analyzed in this study.

\begin{tabular}{cccc}
\hline Species & Sampling Locality/Origin & Environment & $\begin{array}{c}\text { Number of Samples } \\
\text { (F + M + ND) }\end{array}$ \\
\hline O. argentinensis & Los Pocitos, San Blás (ARG) & Marine & $10(6+4+0)$ \\
O. humensis & Mirin Lagoon, Taim (BRA) & Inland water & $20(4+14+2)$ \\
O. incisa & Mar del Plata (ARG) & Marine & $35(26+9+0)$ \\
O. mauleanum & Valdivia (CHI) & Estuarine & $24(8+14+2)$ \\
O. mirinensis & Mirin Lagoon, Taim (BRA) & Inland water & $21(7+14+0)$ \\
O. nigricans & Punta María (ARG) & Marine & $12(7+5+0)$ \\
O. perugiae & Cambe Cué Lagoon, Corrientes (ARG) & Inland water & $16(0+0+16)$ \\
O. piquava & Paraná River, Encarnación (PAR) & Inland water & $10(3+7+0)$ \\
O. regia & Tramandaí Lagoon, Tramandaí (BRA) & Estuarine & $21(13+7+1)$ \\
O. smitti & Playa Blanca, Iquique (CHI) & Marine & $36(31+5+0)$ \\
Total & Mar del Plata (ARG) & Marine & $4(2+2+0)$ \\
PRanta María (ARG) & Marine & $12(6+6+0)$ \\
\hline
\end{tabular}

ARG: Argentina; BRA: Brazil; PAR: Paraguay; CHI: Chile; F: female; M: male; ND: not determined.

\subsection{Phenotypic Sex Determination}

The majority of the specimens were sexed by direct observation of oocytes or milt upon application of abdominal pressure or by macroscopic inspection of the gonads. In O. perugiae, gonads were processed by histological analysis. For this purpose, fish were fixed in Bouin's solution overnight and then preserved in $70 \%$ ethanol. The trunk region that contained the gonad was embedded in paraffin and transversally sectioned at a thickness of $6 \mu \mathrm{m}$. Sections were stained with hematoxylin-eosin and examined under a microscope while using criteria described previously [10].

\subsection{DNA Extraction and Sex Genotyping by amhy Amplification}

Total DNA extraction from caudal fin or muscle and PCR using primer sets described in Table S1 were performed following our previous study [10]. The amplification conditions for both primer sets consisted of $3 \mathrm{~min}$ at $94{ }^{\circ} \mathrm{C}$, followed by 35 cycles of $30 \mathrm{~s}$ at $94{ }^{\circ} \mathrm{C}, 30 \mathrm{~s}$ at $60{ }^{\circ} \mathrm{C}$, and $2 \mathrm{~min}$ at 
$72{ }^{\circ} \mathrm{C}$, and a final elongation for $5 \mathrm{~min}$ at $72{ }^{\circ} \mathrm{C}$. PCR products were electrophoresed in $1 \%$ agarose gel and stained with ethidium bromide or SYBR ${ }^{\circledR}$ Safe DNA gel stain (Invitrogen, Carlsbad, CA, USA). Samples without amhy amplification ( $\left.a m h y^{-}\right)$were denoted as $\mathrm{XX}$, whereas those with amhy amplification $\left(a m h y^{+}\right)$were scored as $\mathrm{XY} / \mathrm{YY}$, because this assay does not distinguish hetero- from homozygotes. Two amhy-positive individuals each from samples of O. argentinensis, O. incisa, O. regia, and O. smitti were selected for the complete sequencing of amhy and amha genes, with the purpose of assessing its conservation in terms of Odontesthes species taxonomy and also gene structure. These four species, in addition to $O$. hatcheri and $O$. bonariensis, were chosen as to represent the main taxonomic clades of Odontesthes [21]. Fragments were excised from the gel, purified while using illustra ${ }^{\mathrm{TM}}$ GFX PCR DNA and Gel Band Purification kit (GE Healthcare Life Sciences, Buckinghamshire, UK), labeled with Big Dye Terminator v3.1 Cycle Sequencing Kit (ABI, Foster City, CA, USA), and sequenced in both directions by the ABI PRISM $₫ 3130 X \mathrm{~L}$ capillary sequencer using primers from Table $\mathrm{S} 1$. The sequences were analyzed using GENETYX v. 11 (Genetyx Corporation, Tokyo, Japan) and then deposited on GenBank (NCBI accession codes: \#MN380791; \#MN380792, \#MN380793, \#MN380794, \#MN380795, \#MN380796, \#MN380797, and \#MN380798).

\section{Results}

Amha was present in all specimens, regardless of species and sex, whereas amhy was amplified in most but not all phenotypic males. The full sequence of amhy isolated for four key species revealed the characteristic features of $O$. hatcheri amhy. Complete association between amhy-homologue with maleness was found in all species, except in O. humensis, O. mirinensis, and O. nigricans.

\subsection{Amplification and Sequencing of amhy and amha Genes}

PCR using the primer set that amplifies both amha and amhy genes in O. hatcheri generally resulted in two bands in males and one in females of most of the specimens examined, except in O. humensis, $O$. mirinensis, and O. nigricans (see details of genotype/phenotype agreement in the next section). The approximate band sizes did not differ from those of O. hatcheri (Figure 2A; the pattern of two bands is shown), which have $1614 \mathrm{bp}$ and $1057 \mathrm{bp}$, respectively, for amhy and amha. Sequence analysis of amhy and amha in four species (O. argentinensis, O. incisa, O. regia, and O. smitti) revealed the presence of the characteristic insertion in the third intron of amhy homologue (Figure 2B), which was slightly larger in O. incisa (525 bp) than in other species (513 bp) (Figure 2C). The nucleotide identity between the open reading frame (ORF) of both genes was $95 \%$ in all four species (Figure 2C). The alignment of predicted amino acid (aa) sequence with amhy of $O$. hatcheri, and $O$. bonariensis showed the conserved insertion and deletion in the $\mathrm{N}$-terminal region of protein, which are not present in the amha homologue: a 2 and 5 amino acid insertion in the position +20 and +111 , respectively, and a 1 amino acid deletion in the position +47 (Figure 3). The N-terminal was shown to be a more variable region than the C-terminal domain. 

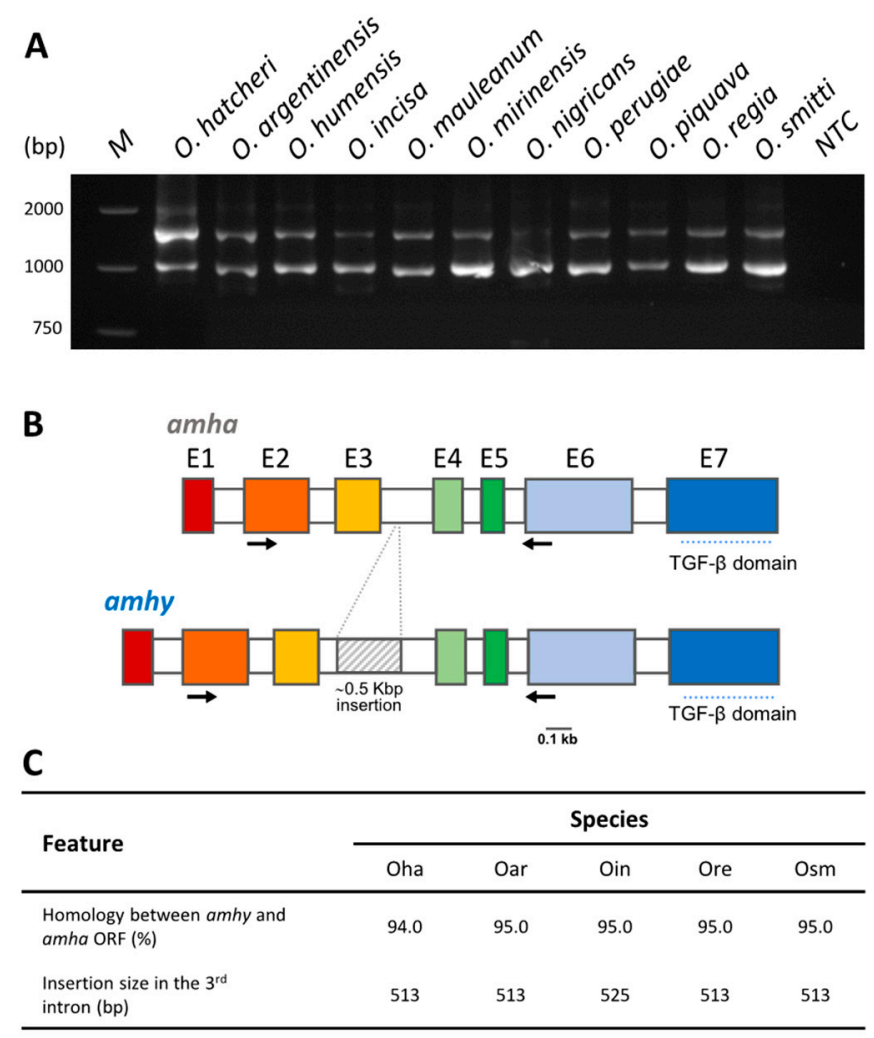

Figure 2. amhy gene amplification pattern, gene structure, and nucleotide sequence comparison Odontesthes species. (A) Pattern of amhy (upper band) and amha (lower band) amplification using primers flanking the third intron in presumable genotypic males. M: molecular weight marker; NTC: non-template control. (B) Schematic representation of amhy and amha gene structure in the four key Odontesthes species. Exons (E1 to E7) are represented by colored boxes and introns by open boxes; corresponding exons of each locus are represented by the same color. The gray box represents the insertion in the third intron. Arrows indicate the position of primers used in (A). (C) Nucleotide identity comparison of predicted amha and amhy Open reading frames and the size of insertion in the third intron. Oha: Odontesthes hatcheri; Oar: O. argentinensis; Oin: O. incisa; Ore: O. regia; Osm: O. smitti. 


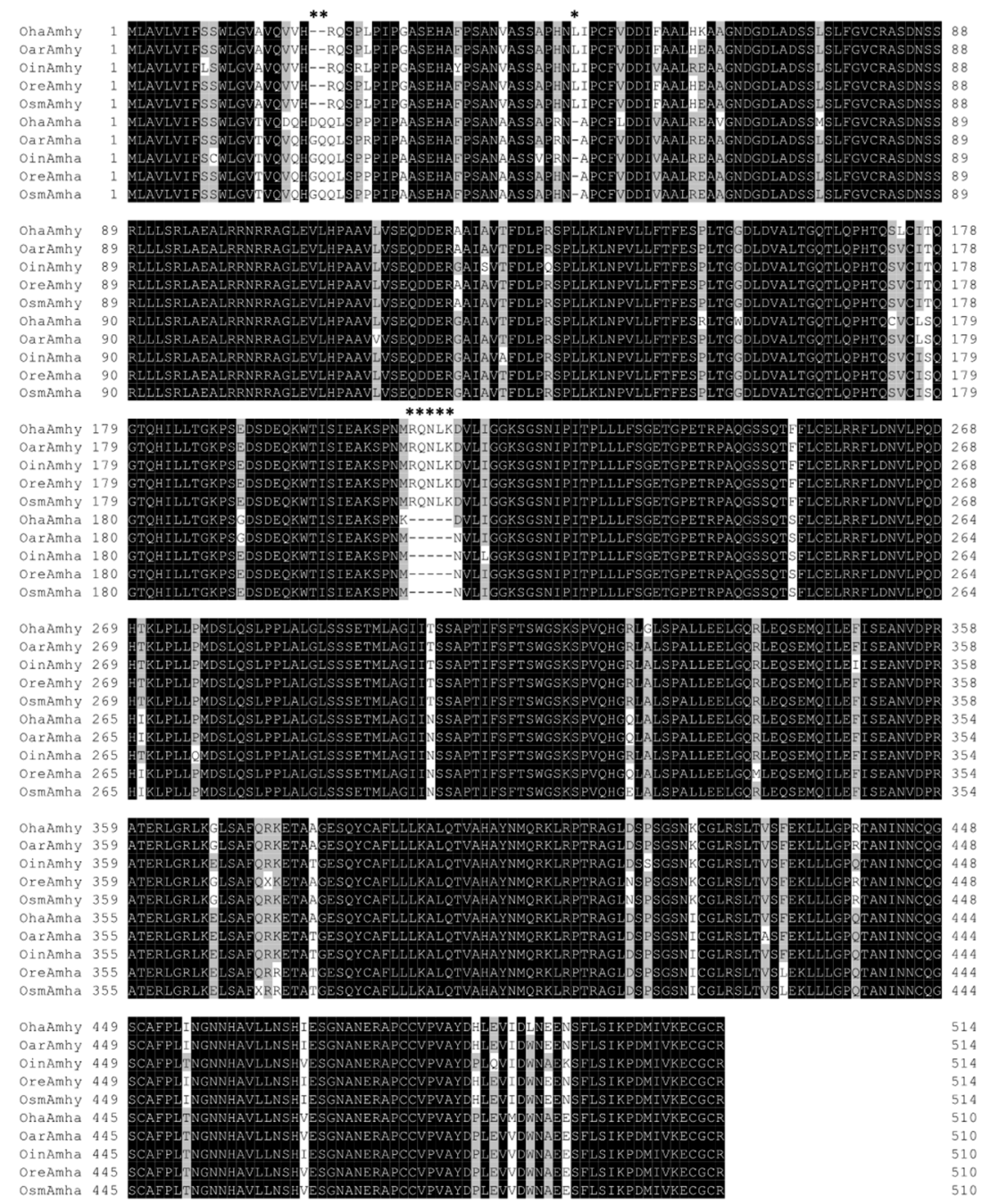

Figure 3. Alignment of the predicted amino acid sequences of amha and amhy genes in four Odontesthes species. Oha: Odontesthes hatcheri; Oar: O. argentinensis; Oin: O. incisa; Ore: O. regia; Osm: O. smitti. Identical residues and conserved substitutions are highlighted by black and gray background, respectively. Asterisks represent conserved insertions and deletion. The boxed region represents the TGF-beta domain with conserved seven canonical cystein residues (S).

\subsection{Correlation Between the Presence of amhy and Phenotypic Sex}

Mismatches between the genotypic sex (XY/YY or XX), inferred from the presence or absence of $a m h y$, respectively, and the phenotypic sex were identified in three species (Table 2). Odontesthes mirinensis had the highest mismatch (sex reversal) rate (38.1\%), followed by O. nigricans $(33.3 \%)$ and O. humensis (25\%). In the three species, the percentages of female-to-male sex reversal were higher than those of male-to-female (Table 2). 
Table 2. Correlation between genotypic and phenotypic sex in Odontesthes species.

\begin{tabular}{|c|c|c|c|c|c|c|}
\hline \multirow[t]{2}{*}{ Species (Population) } & \multicolumn{2}{|c|}{$\begin{array}{l}a m h y^{+} \\
(\mathrm{XY} / \mathrm{YY})\end{array}$} & \multirow{2}{*}{$\begin{array}{c}\text { Sex Reversal } \\
(\%)\end{array}$} & \multicolumn{2}{|c|}{$\begin{array}{c}a m h y^{-} \\
(X X)\end{array}$} & \multirow{2}{*}{$\begin{array}{c}\text { Sex Reversa } \\
(\%)\end{array}$} \\
\hline & $\mathbf{F}$ & $\mathbf{M}$ & & $\mathbf{F}$ & $\mathbf{M}$ & \\
\hline O. argentinensis & 0 & 4 & 0 & 6 & 0 & 0 \\
\hline O. humensis & 1 & 12 & $1(7.7)$ & 2 & 1 & $1(33.3)$ \\
\hline O. incisa * & 0 & 6 & 0 & 21 & 0 & 0 \\
\hline O. mauleanum & 0 & 3 & 0 & 5 & 0 & 0 \\
\hline O. mirinensis & 3 & 9 & $3(33.3)$ & 4 & 5 & $5(55.6)$ \\
\hline O. nigricans & 0 & 2 & 0 & 6 & 4 & $4(40)$ \\
\hline O. perugiae (Paraná River pop.) & 0 & 7 & 0 & 3 & 0 & 0 \\
\hline O. piquava* & 0 & 2 & 0 & 13 & 0 & 0 \\
\hline O. regia* & 0 & 5 & 0 & 31 & 0 & 0 \\
\hline O. smitti (Mar del Plata pop.) & 0 & 2 & 0 & 2 & 0 & 0 \\
\hline (Punta Maria pop.) & 0 & 6 & 0 & 6 & 0 & 0 \\
\hline
\end{tabular}

$a m h y^{+}$: samples with amhy amplification; amhy-: samples without amhy amplification. Asterisks $\left({ }^{*}\right)$ after the species name indicate that phenotypic sex ratios differ significantly from 1:1. Pop.: population; F: female; M: male.

\section{Discussion}

The silversides (Atheriniformes) stand out among the group of teleosts with temperature-dependent sex determination, because of the high sensitiveness of their gonads to both high (masculinizing) and low (feminizing) temperatures during early life [22,23]. The discovery of the testis-determining gene amhy in some of these species has provided a valuable tool in the research on interactions between sex determination mechanisms in this group of fishes $[11,12,17]$. The presence of amhy orthologue was investigated in South American silversides in order to increase the usefulness of silversides on sex determination research and to try to trace back the evolution of amhy.

Homologues of amhy and amha genes of $O$. hatcheri [10] were successfully found in all of the Odontesthes species examined. The amhy showed a high genetic association with maleness in most species, with the exception of three species, in which mismatches between genotypic and phenotypic sex were relatively frequent and supposedly caused by sex reversal due to environmental conditions [23] (see discussion below). Sequence analyses of amhy coding and non-coding regions in the four selected species confirmed the characteristics indels in the N-terminal region of the protein and the insertion of about $0.5 \mathrm{Kbp}$ in the third intron, as also found in O. bonariensis [11], which suggested a conserved structure of amhy in Odontesthes species. Although the third intron insertion was slightly longer in O. incisa, other introns and also the TGF-beta domain also showed a high conservation in terms of size and nucleotide sequence between the four species. These results, together with high genetic association of amhy with maleness in most of the species, suggest that amhy is likely a functional and conserved sex-determining gene in most, if not all, Odontesthes species.

The Odontesthes genus comprises over 16 species described and recent phylogenetic analyses by mitochondrial and nuclear genes have proposed the $O$. smitti and O. nigricans as the most plesiomorphic species [21]. The presence of amhy in this basal group supports the appearance of amhy at least before or during the rise of Odontesthes genus, which is estimated between around 5 and 20 million of years ago [21]. The search for amhy or alternative sex-determining genes has now been expanded to include other Atheriniforms, such as atherinopsids of the Basilichthys genus, sister genus of Odontesthes, North American atherinopsids, and atherinids. A constraint for the identification of sex-determining genes lies on their higher substitution rates when compared to the respective paralogues, based on comparative analysis on $d m y, D M-W$, and $S R Y$ genes [24]. For example, a duplicated amh that was highly linked to maleness has been recently identified in an Old World Atheriniform (Atherinidae), the cobaltcap silverside Hypoatherina tsurugae [12]. However, the amhy-like gene in this species has surprisingly lost two exons during its evolution, thus acquiring a truncated gene structure. For that reason, it is still uncertain whether the cobaltcap "amhy" is orthologous to the amhy that was identified in Odontesthes genus. Another constraint is related to the high sensitivity of sex to environmental conditions in many of these members [25-28], which can give rise to mismatch between genotypic sex and phenotypic sex in the wild. Nevertheless, the discovery of amhy or alternative sex-determining 
genes can help to shed light on the evolution and interaction of both genotypic and environmental sex determination in atheriniforms.

The analysis of genotypic sex based on sex-determining gene presence/absence evidenced the occurrence of sex mismatches in several species. A comparative analysis between species that takes the type of habitat into consideration points to a trend of higher sex reversal rates in inland waters as compared to marine or estuarine environments. Sex reversal occurred in both directions in O. humensis and O. mirinensis, with $\mathrm{XY} / \mathrm{YY}$ females (feminization) and $\mathrm{XX}$ males (masculinization), similarly to the reported in O. bonariensis [11,17], which also inhabits shallow lakes. It is still unknown if such sex-reversed animals are formed naturally as part of the species reproductive strategy or if they are the consequence of changes in natural environments, such as global climate change. For instance, environmentally relevant low and high temperatures effectively feminize and masculinize many silversides, respectively [23]. It must be pointed out that, although the current scenario of global climate change points to a gradual increase in water and air temperature, climatic events with unusually low temperatures have also been recorded rather frequently [29]. Alternatively, the release of endocrine-disrupting chemicals with androgenic or estrogenic effect or alterations in habitats due to anthropogenic activities can also account for sex reversal in the wild [30-32]. The morphology of lakes in the South-Eastern region of South America (shallow and small volume) make them highly vulnerable to environmental changes. On the other hand, marine and estuarine regions have per se a higher buffer potential, and therefore comprise environments that are more resilient to alterations in the physical and chemical factors. Nevertheless, periodic field surveys in various types of environments in combination with tools for recording the temperature experienced by fish during the early life stages can contribute to strengthening the correlations between phenotype and environment.

Overall, the amhy gene comprises a biomarker of genetic sex with a wide usefulness that ranged from evolution studies of sex-determining mechanism in fish to ecological studies, like the direct monitoring of natural populations $[17,33]$. According to the status of these wild populations, amhy could also be used for restocking programs, whereby distortions in the sex genotype/phenotype could be mitigated by releases of seeds with the appropriate combination of genotypes and phenotypes. The identification of amhy in other groups may increase the potential of silversides in studies regarding the assessment of climate change impacts on fish sex determination and population structure.

\section{Conclusions}

In conclusion, this study showed that the amhy gene is structurally conserved and has a high genetic association with maleness along the main clades of the genus Odontesthes. The presence of a genotypic sex determinant provides a useful tool for studies on the evolution of and the ecological interactions between genotypic and environmental sex determination in this group.

Supplementary Materials: The following are available online at http://www.mdpi.com/2073-4425/10/9/679/s1, Table S1: List of primers used to amplify and sequence the cytb gene and the homologues of amha and amhy.

Author Contributions: Formal analysis, R.S.H., G.M.S., J.I.F., D.C.C., K.M., Z.G. and Y.Y.; Project administration, R.S.H.; Supervision, C.A.S.; Writing—original draft, R.S.H.; Writing—review \& editing, G.M.S., J.I.F., Y.Y. and C.A.S.

Funding: This work was supported by FAPESP grant to RSH (09/15877-0) and JSPS KAKENHI grants to YY (19H03048) and CAS (19H01162).

Acknowledgments: We would like to give thanks to Mr. Carlos Lopes from the Institute of Biosciences, Sao Paulo University, for samples processing. We also thank reviewers for insightful comments on this article.

Conflicts of Interest: The authors declare no conflicts of interest.

\section{References}

1. Hattori, R.S.; Strüssmann, C.A.; Fernandino, J.I.; Somoza, G.M. Genotypic sex determination in teleosts: Insights from the testis-determining amhy gene. Gen. Comp. Endocrinol. 2013, 192, 55-59. [CrossRef] 
2. Kikuchi, K.; Hamaguchi, S. Novel sex-determining genes in fish and sex chromosome evolution. Dev. Dyn. 2013, 242, 339-353. [CrossRef]

3. Devlin, R.H.; Nagahama, Y. Sex determination and sex differentiation in fish. Aquaculture 2002, 208, $191-364$. [CrossRef]

4. Takehana, Y.; Matsuda, M.; Myosho, T.; Suster, M.L.; Kawakami, K.; Shin-I, T.; Kohara, Y.; Kuroki, Y.; Toyoda, A.; Fujiyama, A.; et al. Co-option of Sox3 as the male-determining factor on the y chromosome in the fish Oryzias dancena. Nat. Commun. 2014, 5, 4157. [CrossRef]

5. Matsuda, M.; Nagahama, Y.; Shinomiya, A.; Sato, T. DMY is a Y-specific DM-domain gene required for male development in the medaka fish. Nature 2002, 399, 559-563. [CrossRef]

6. Myosho, T.; Otake, H.; Masuyama, H.; Matsuda, M.; Kuroki, Y.; Fujiyama, A.; Naruse, K.; Hamaguchi, S.; Sakaizumi, M. Tracing the emergence of a novel sex-determining gene in medaka, Oryzias luzonensis. Genetics 2012, 191, 163-170. [CrossRef]

7. Yano, A.; Guyomard, R.; Nicol, B.; Jouanno, E.; Quillet, E.; Klopp, C.; Cabau, C.; Bouchez, O.; Fostier, A.; Guiguen, Y. An immune-related gene evolved into the master sex-determining gene in rainbow trout, Oncorhynchus mykiss. Curr. Biol. 2012, 22, 1423-1428. [CrossRef]

8. Yano, A.; Nicol, B.; Jouanno, E.; Quillet, E.; Fostier, A.; Guyomard, R.; Guiguen, Y. The sexually dimorphic on the $\mathrm{Y}$-chromosome gene $(s d Y)$ is a conserved male-specific $\mathrm{Y}$-chromosome sequence in many salmonids. Evol. Appl. 2013, 6, 486-496. [CrossRef]

9. Pfennig, F.; Standke, A.; Gutzeit, H.O. The role of Amh signaling in teleost fish-Multiple functions not restricted to the gonads. Gen. Comp. Endocrinol. 2015, 223, 87-107. [CrossRef]

10. Hattori, R.S.; Murai, Y.; Oura, M.; Masuda, S.; Majhi, S.K.; Sakamoto, T.; Fernandino, J.I.; Somoza, G.M.; Yokota, M.; Strussmann, C.A. A Y-linked anti-Mullerian hormone duplication takes over a critical role in sex determination. Proc. Natl. Acad. Sci. USA 2012, 109, 2955-2959. [CrossRef]

11. Yamamoto, Y.; Zhang, Y.; Sarida, M.; Hattori, R.S.; Strüssmann, C.A. Coexistence of genotypic and temperature-dependent sex determination in pejerrey Odontesthes bonariensis. PLoS ONE 2014, 9, e102574. [CrossRef]

12. Bej, D.K.; Miyoshi, K.; Hattori, R.S.; Strüssmann, C.A.; Yamamoto, Y. A Duplicated, Truncated amh Gene Is Involved in Male Sex Determination in an Old World Silverside. G3 Genes Genomes Genet. 2017, 7, 2489-2495. [CrossRef]

13. Li, M.; Sun, Y.; Zhao, J.; Shi, H.; Zeng, S.; Ye, K.; Jiang, D.; Zhou, L.; Sun, L.; Tao, W.; et al. A Tandem Duplicate of Anti-Müllerian Hormone with a Missense SNP on the Y Chromosome Is Essential for Male Sex Determination in Nile Tilapia, Oreochromis niloticus. PLoS Genet. 2015, 11, e1005678. [CrossRef]

14. Pan, Q.; Feron, R.; Yano, A.; Guyomard, R.; Jouanno, E.; Vigouroux, E.; Wen, M.; Busnel, J.-M.; Bobe, J.; Concordet, J.-P.; et al. Identification of the master sex determining gene in Northern pike (Esox lucius) reveals restricted sex chromosome differentiation. PLoS Genet. 2019, 15, e1008013. [CrossRef]

15. Kamiya, T.; Kai, W.; Tasumi, S.; Oka, A.; Matsunaga, T.; Mizuno, N.; Fujita, M.; Suetake, H.; Suzuki, S.; Hosoya, S.; et al. A trans-species missense SNP in Amhr2 is associated with sex determination in the tiger Pufferfish, Takifugu rubripes (Fugu). PLoS Genet. 2012, 8, e1002798. [CrossRef]

16. Ieda, R.; Hosoya, S.; Tajima, S.; Atsumi, K.; Kamiya, T.; Nozawa, A.; Aoki, Y.; Tasumi, S.; Koyama, T.; Nakamura, O.; et al. Identification of the sex-determining locus in grass puffer (Takifugu niphobles) provides evidence for sex-chromosome turnover in a subset of Takifugu species. PLoS ONE 2018, 13, e0190635. [CrossRef]

17. Hattori, R.S.; Tashiro, S.; Zhang, Y.; Kakuta, N.; Yokota, M.; Strüssmann, C.A.; Yamamoto, Y. Demonstration of viability and fertility and development of a molecular tool to identify YY supermales in a fish with both genotypic and environmental sex determination. Ecol. Evol. 2018, 8, 7522-7528. [CrossRef]

18. Dyer, B.S. Systematic revision of the South American silversides (Teleostei, Atheriniformes). Biocell 2006, 30, 69-88.

19. Muñoz, C.; Nirchio, M.; Pérez, J.E.; Ron, E.; Oliveira, C.; Ferreira, I.A. Cytogenetic characterization of the silverside fish Odontesthes regia (Humboldt, 1833) (Teleostei: Atheriniformes: Atherinopsidae) from Iquique, Chile. Rev. Biol. Mar. Oceanogr. 2006, 41, 57-62. [CrossRef]

20. Sola, L.; Natili, G.L.; Cataudella, S. Cytogenetical characterization of Odontesthes bonariensis (Pisces, Atherinidae), an Argentine species introduced in Italy. Genetica 1988, 77, 217-224. [CrossRef] 
21. Campanella, D.; Hughes, L.C.; Unmack, P.J.; Bloom, D.D.; Piller, K.R.; Ortí, G. Multi-locus fossil-calibrated phylogeny of Atheriniformes (Teleostei, Ovalentaria). Mol. Phylogenet. Evol. 2015, 86, 8-23. [CrossRef]

22. Fernandino, J.I.; Hattori, R.S.; Strüssmann, C.A.; Yamamoto, Y.; Somoza, G.M. Sex determination in fish: Odontesthes spp. (Atherinopsidae) as experimental models. Anim. Reprod. 2015, 12, $24-27$.

23. Yamamoto, Y.; Hattori, R.S.; Patiño, R.; Strüssmann, C.A. Environmental regulation of sex determination in fishes: Insights from Atheriniformes. Curr. Top. Dev. Biol. 2019, 134, 49-69.

24. Mawaribuchi, S.; Yoshimoto, S.; Ohashi, S.; Takamatsu, N.; Ito, M. Molecular evolution of vertebrate sex-determining genes. Chromosome Res. 2012, 20, 139-151. [CrossRef]

25. Conover, D.O.; Voorhees, D.A.V.; Ehtisham, A. Sex Ratio Selection and the Evolution of Environmental Sex Determination in Laboratory Populations of Menidia menidia. Evolution (N. Y.) 2006, 46, 1722-1730.

26. Corona-Herrera, G.A.; Tello-Ballinas, J.A.; Hattori, R.S.; Martínez-Palacios, C.A.; Strüssmann, C.A.; Cárdenas-Reygadas, R.R.; Martínez-Chávez, C.C. Gonadal differentiation and temperature effects on sex determination in the freshwater pike silverside Chirostoma estor Jordan 1880. Environ. Biol. Fishes 2016, 99, 463-471. [CrossRef]

27. Brown, E.E.; Baumann, H.; Conover, D.O. Temperature and photoperiod effects on sex determination in a fish. J. Exp. Mar. Bio. Ecol. 2014, 461, 39-43. [CrossRef]

28. Strüssmann, C.A.; Patiño, R. Sex determination, Environmental. In Encyclopedia of Reproduction; Knobil, E., Neil, J.D., Eds.; Academic Press: San Diego, CA, USA, 1999; pp. 402-409.

29. Peterson, T.C.; Stott, P.A.; Herring, S. Explaining Extreme Events of 2011 from a Climate Perspective. Bull. Am. Meteorol. Soc. 2012, 93, 1041-1067. [CrossRef]

30. Gelca, R.; Hayhoe, K.; Scott-Fleming, I.; Crow, C.; Dawson, D.; Patiño, R. Climate-water quality relationships in Texas reservoirs. Hydrol. Process. 2016, 30, 12-29. [CrossRef]

31. Strüssmann, C.A.; Conover, D.O.; Somoza, G.M.; Miranda, L.A. Implications of climate change for the reproductive capacity and survival of New World silversides (family Atherinopsidae). J. Fish Biol. 2010, 77, 1818-1834. [CrossRef]

32. Duffy, T.A.; Mcelroy, A.E.; Conover, D.O. Variable susceptibility and response to estrogenic chemicals in Menidia Menidia. Mar. Ecol. Prog. Ser. 2009, 380, 245-254. [CrossRef]

33. Fernandino, J.I.; Hattori, R.S. Sex determination in Neotropical fish: Implications ranging from aquaculture technology to ecological assessment. Gen. Comp. Endocrinol. 2019, 273, 172-183. [CrossRef] 